\title{
Lower oesophageal sphincter hypersensitivity to opioid receptor stimulation in patients with idiopathic achalasia
}

\author{
R Penagini, B Bartesaghi, P Zannini, G Negri, P A Bianchi
}

\begin{abstract}
Impairment of non-cholinergic innervation of the lower oesophageal sphincter has been suggested in idiopathic achalasia. As opioid nerves are present in the lower oesophageal sphincter and opioid peptides affect lower oesophageal sphincter motility, the effect of an opioid agonist, morphine $(100 \mu \mathrm{g} / \mathrm{kg}$ iv $)$, and an opioid blocker, naloxone $(80 \mu \mathrm{g} / \mathrm{kg}$ iv), on lower oesophageal sphincter motor function was assessed in $\mathbf{1 0}$ healthy subjects and in 10 patients with untreated idiopathic achalasia on separate days and in randomised order. In addition, in six of the patients, naloxone $0.8 \mathrm{mg}$ iv was injected 60 minutes after morphine and recordings continued for a further five minutes. Lower oesophageal sphincter pressure was monitored by a sleeve device. In the healthy subjects morphine decreased $(p<0.01)$ resting lower oesophageal sphincter pressure by 4 (1) $\mathrm{mm} \mathrm{Hg}(23(8) \%)$. In the achalasia patients the effect was more marked, lower oesophageal sphincter pressure being reduced $(p<0.01)$ by 11 (2) $\mathrm{mm} \mathrm{Hg}$ (46 (8)\%). Naloxone reversed lower oesophageal sphincter pressure to basal. Both absolute and percentage decreases after morphine were significantly greater $(p<0.05)$ in the achalasia patients than in the healthy subjects. Swallow induced lower oesophageal sphincter relaxation was significantly decreased $(p<0.05)$ by morphine in the healthy subjects but not in the achalasia patients. Naloxone had no effect on resting lower oesophageal sphincter pressure or swallow induced relaxation in either healthy subjects or achalasia patients. In conclusion achalasia patients are hypersensitive to the effect of morphine on resting lower oesophageal sphincter pressure. This finding is unlikely to be the result of a denervation process involving opioid nerves.
\end{abstract}

(Gut 1993; 34: 16-20)

Cattedra di Patologia Medica III, Istituto di Scienze Mediche

R Penagini, B Bartesaghi, P A Bianchi

Istituto di Chirurgia Generale

P Zannini

G Negri

University of Milan, Milan, Italy

Correspondence to:

R Penagini MD, Cattedra d Patologia Medica III, Pad Granelli, Via F Sforza, 35 20122 Milano, Italy.

Accepted for publication

12 June 1992 the postganglionic nerve fibres of the phagus. ${ }^{2}$ During the past years the attention has been focused mainly on the lower oesophageal sphincter, and some results suggest that noncholinergic inhibitory nerves are impaired ${ }^{3+}$ whereas cholinergic innervation is at least partly preserved. . $^{5}$
Opioid nerves have been shown in the myenteric plexus of normal lower oesophageal sphincter in $\operatorname{man}^{8-9}$ and various opioid receptors have been identified in the opossum lower oesophageal sphincter, in the sphincter muscle and the nerve fibres surrounding it. ${ }^{10}$ Furthermore, evidence exists that opioid peptides affect lower oesophageal sphincter motor function..$^{11-15}$ In particular one study ${ }^{14}$ showed that an opioid agonist, morphine, administered to healthy subjects determined a decrease and an opioid blocker, naloxone, an increase, although modest, in lower oesophageal sphincter pressure. The latter finding may suggest that endogenous opioids contribute to the control of lower oesophageal sphincter resting pressure.

We reasoned that if opioid nerves are involved in the denervation process of achalasia, the lower oesophageal sphincter of these patients would show hypersensitivity to opioid receptor stimulation induced by morphine and no effect or hyposensitivity to endogenous opioid blockade by naloxone. Therefore, we studied the effect of morphine and naloxone on lower oesophageal sphincter motor function in 10 patients with idiopathic achalasia and compared the results with those obtained in 10 healthy subjects.

\section{Methods}

\section{SUBJECTS AND PATIENTS}

Ten healthy subjects (aged 19-27 years; eight men) and 10 patients with untreated idiopathic achalasia (aged 25-77 years; four men) were enrolled in the study, which was approved by the Human Research Review Committee of the Ospedale Maggiore of Milan. The patients with achalasia were referred for investigation and treatment of dysphagia which had lasted for three years; 1-10 (median; range). At barium radiograph the oesophageal body, which contained no food residue in any of the patients, had a maximum diameter of $3.9 \mathrm{~cm} ; 2 \cdot 5-6.0$. Four patients have lost weight since the onset of their oesophageal symptoms (3 kg; 0-10). Upper gastrointestinal endoscopy was performed in all patients and no lesions were found at the cardias. Routine oesophageal manometry showed absent peristalsis in the oesophageal body and abnormal $(<80 \%)$ lower oesophageal sphincter relaxation in response to water swallows.
MANOMETRIC RECORDING TECHNIQUE

Oesophageal motility was monitored using an assembly of polyvinyl tubes incorporating a sleeve sensor (Dentsleeve, Belair, Australia). 

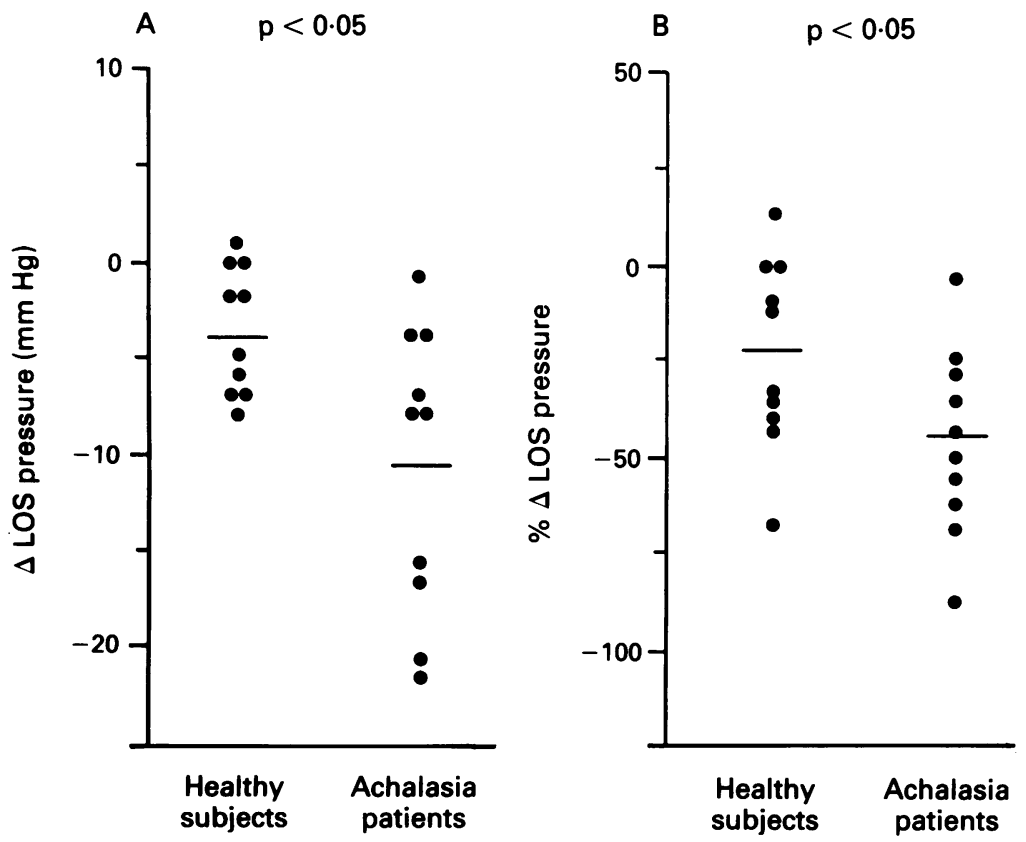

Figure 1: Effect of morphine on resting lower oesophageal sphincter (LOS) pressure. Absolute changes $(\triangle)$ and percentage changes $(\% \triangle)$ of the LOS pressure in healthy subjects and achalasia patients are shown in $A$ and $B$ respectively. Horizontal bars represent means.

The $6 \mathrm{~cm}$ long sleeve was positioned so that it straddled the lower oesophageal sphincter. A side hole $1 \mathrm{~cm}$ below the distal margin of the sleeve recorded intragastric pressure. Side holes at the upper margin of the sleeve and 5 and $10 \mathrm{~cm}$

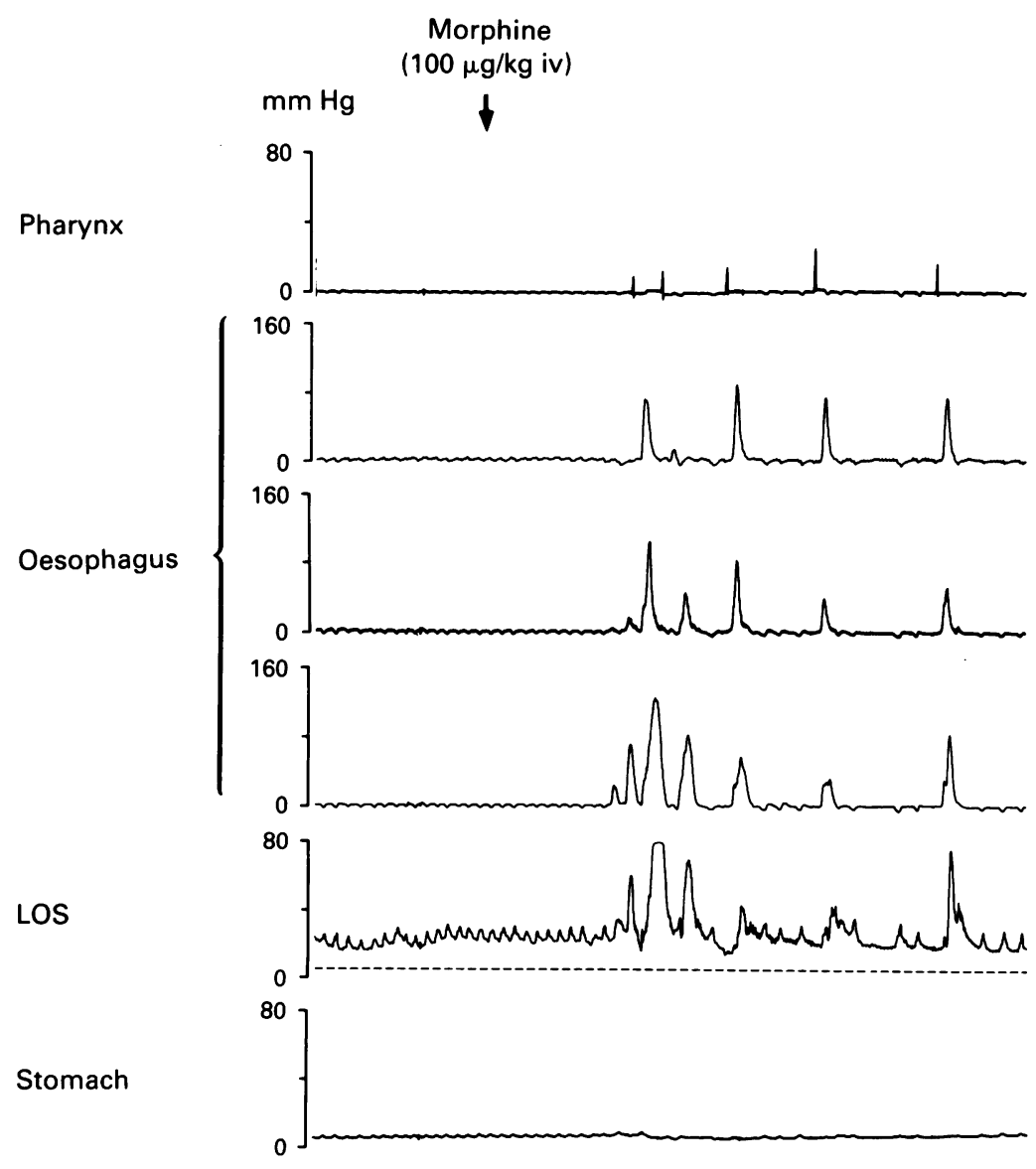

1 minute

Figure 2: Tracing in a healthy subject at the time of morphine injection. Morphine had a minor effect on resting lower oesophageal sphincter $(L O S)$ pressure. A decrease in respiratory rate may be noted. The broken line indicates intragastric pressure. more proximally monitored motor activity of the oesophageal body at levels 2,7 and $12 \mathrm{~cm}$ above the lower oesophageal sphincter. Furthermore, one of two side holes at 23 and $28 \mathrm{~cm}$ proximal to the upper margin of the sleeve monitored swallows in the pharynx in all but four patients. Each lumen was connected to a pressure transducer (model 4-327-I, Sensormedics, Anaheim, CA, USA) and perfused with distilled water by a low compliance pneumohydraulic infusion pump (Sensormedics, Milan, Italy; response: $>200 \mathrm{~mm} \mathrm{Hg} / \mathrm{s}$ at $0.5 \mathrm{ml} /$ minute) except for the pharyngeal port, which was water filled, but not perfused to avoid stimulation of swallowing. The gastric side hole and sleeve were perfused at 0.5 $\mathrm{ml} /$ minute, whereas the side holes in the oesophageal body were perfused at $0.13 \mathrm{ml} /$ minute in order to minimise the fluid load to the subject. Signal from the pressure transducers were processed and recorded on a polygraph (model R711, Sensormedics, Anaheim, CA, USA) at a paper speed of $1 \mathrm{~mm} / \mathrm{s}$.

\section{EXPERIMENTS}

Oesophageal motility was recorded in the subjects and patients after an overnight fast during two experiments performed in randomised order on two separate days, according to the same protocol. Each experiment comprised a 30 minute basal period and a 60 minute period after intravenous injection of either morphine $(100 \mu \mathrm{g} / \mathrm{kg})$ or naloxone $(80 \mu \mathrm{g} / \mathrm{kg})$ as a bolus. No observations were obtained after naloxone in two of the patients, one refused to perform his second experiment and the other tolerated it poorly and failed to complete it. In the last six patients $0.8 \mathrm{mg}$ of naloxone was injected iv at the end of the morphine period and recording continued for a further five minutes. Although the small dose of naloxone was administered to block the central nervous system effect of morphine, ${ }^{16}$ we felt it of interest to include manometric tracings after naloxone in the analysis. Furthermore, in six of the healthy subjects and in the patients who had tolerated water swallows well during routine manometry (eight) lower oesophageal sphincter relaxation in response to six to eight water $(5 \mathrm{ml})$ swallows per period was assessed. Subjects and patients were recumbent throughout the experiments.

\section{ANALYSIS OF RECORDS}

The pressure tracings were analysed by one of the investigators who was unaware of the drug tested. The effect of the two drugs on resting lower oesophageal sphincter pressure was evaluated as follows. Increases in lower oesophageal sphincter pressure were assessed by comparing the highest end expiratory lower oesophageal sphincter pressure occurring during a two minute interval immediately before drug administration with the highest end expiratory pressure occurring one to three minutes after it. Decreases in lower oesophageal sphincter pressure were assessed by comparing the lowest end expiratory lower oesophageal sphincter pressure occurring during a two minute interval immediately before drug administration with the 


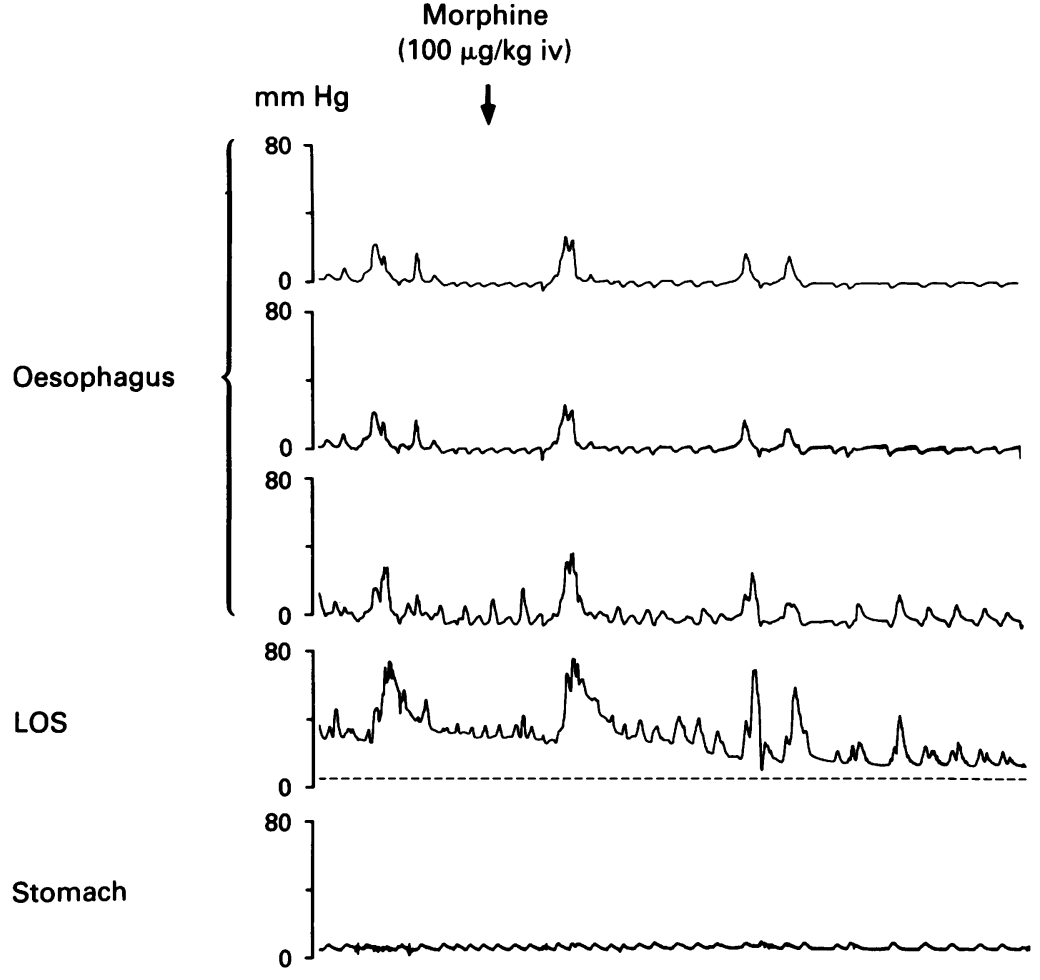

Figure 3: Tracing in a patient with achalasia at the time of morphine injection. $A$ marked relaxation of the lower oesophageal sphincter (LOS) occurred after morphine. A decrease in respiratory rate may also be observed. The broken line indicates intragastric pressure.
1 minute
Figure 4: Mean resting lower oesophageal sphincter (LOS) pressure before and after morphine in healthy subjects ( $\square-\square)$ and achalasia patients (O....)

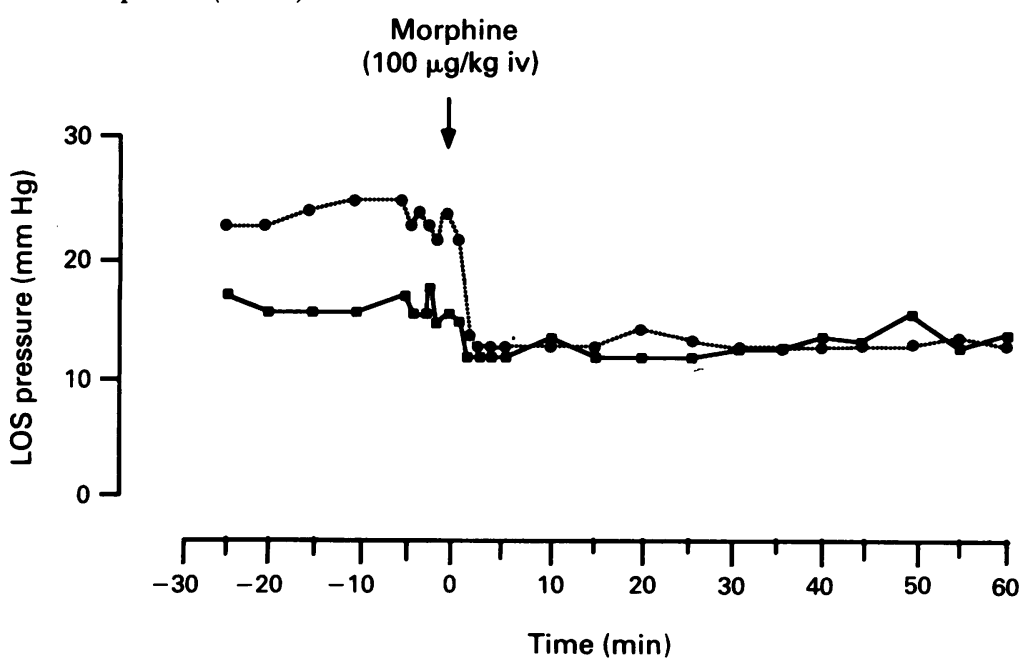

periods were not included in the analysis to avoid an unwanted source of variation. The effect. of the two drugs on swallow induced lower oesophageal sphincter relaxation was evaluated by counting residual lower oesophageal sphincter pressure and percentage lower oesophageal sphincter relaxation. To calculate the latter, lower oesophageal sphincter pressure of the 15 seconds before that swallow was taken as reference pressure.

\section{STATISTICAL ANALYSIS}

Paired and unpaired Student's $t$ tests were used for statistical analysis of results except for the time course of lower oesophageal sphincter pressure changes after drug injection for which Dunnett's test for multiple comparisons involving a control mean was used. Results were expressed as mean (SEM).

\section{Results}

The mean dose of morphine was $6.8 \mathrm{mg}$ in the achalasia patients and $6.6 \mathrm{mg}$ in the healthy subjects, and the dose of naloxone was $5.6 \mathrm{mg}$ and $5 \cdot 3 \mathrm{mg}$ respectively.

Resting lower oesophageal sphincter pressure in the basal period was significantly higher in the achalasia patients, 24 (3) $\mathrm{mm} \mathrm{Hg}$, than in the healthy subjects, $16(1) \mathrm{mm} \mathrm{Hg}(\mathrm{p}<0.05)$. In the latter group morphine determined a decrease of lower oesophageal sphincter pressure of 4 (1) $\mathrm{mm} \mathrm{Hg}(\mathrm{p}<0.01)$, corresponding to $23(8) \%$ (Figs 1,2$)$. In the achalasia patients morphine had a more marked effect on lower oesophageal sphincter pressure, which decreased by 11 (2) $\mathrm{mm} \mathrm{Hg}(\mathrm{p}<0.01)$, corresponding to $46(8) \%$ (Figs 1, 3). Both absolute and percentage lower oesophageal sphincter pressure falls were greater $(p<0.05)$ in the patients than in the healthy subjects. Furthermore, analysis of the time course of lower oesophageal sphincter pressure changes after morphine (Fig 4) showed that in the healthy subjects the effect of the drug was gradually lost and lower oesophageal sphincter pressure was no longer significantly lower than before drug injection by 30 minutes. In the achalasia patients, on the contrary, lower oesophageal sphincter pressure remained steadily and significantly $(\mathrm{p}<0 \cdot 01)$ lower than before drug injection for the whole 60 minute observation period. In the six patients to whom naloxone was administered 60 minutes after morphine lower oesophageal sphincter pressure increased to values similar to basal ones $(p=n s)$ by two minutes after injection (Fig 5 ). Morphine significantly decreased $(p<0.05)$ swallow induced lower oesophageal sphincter relaxation in the healthy subjects, but not in the achalasia patients (Table). It may be noted that in the patients lower oesophageal sphincter relaxation was already very poor in basal conditions and after morphine it showed a slight further decrease in only five of the eight patients tested. Paradoxically, in the patients residual lower oesophageal sphincter pressure was lower $(p<0.05)$ after morphine, a finding which is explained by the marked effect of the drug on resting lower oesophageal sphincter pressure. 
Naloxone

(0.8 $\mathrm{mg}$ iv)
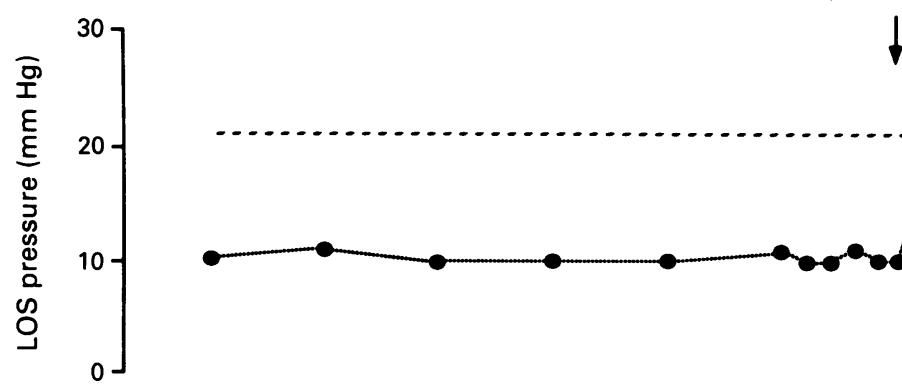

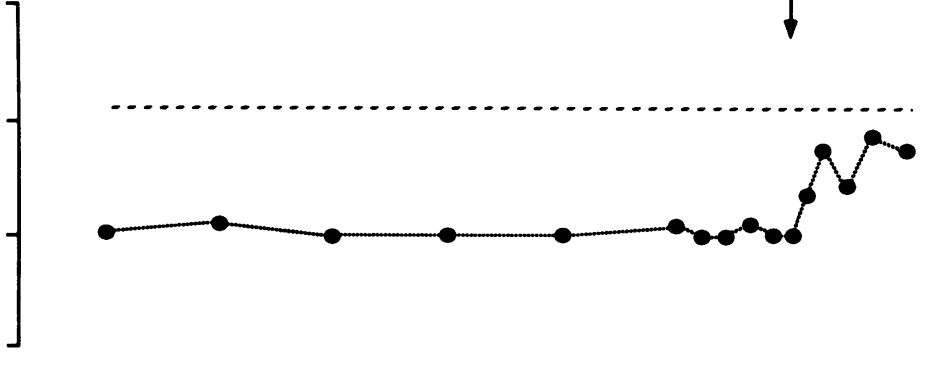

30

35

40

45

50

55

60

Time (min after morphine injection)

Figure 5: Mean resting lower oesophageal sphincter (LOS) pressure of 6 patients with achalasia at the time of naloxone injection showing reversal of the effect of morphine. The broken line indicates mean LOS pressure of the five minutes before morphine injection.

Figure 6: Effect of naloxone on resting lower oesophageal sphincter (LOS) pressure. Absolute changes $(\triangle)$ and percentage changes $(\% \triangle)$ of LOS pressure in healthy subjects and achalasia patients are shown in $A$ and $B$ respectively. Horizontal bars represent means.

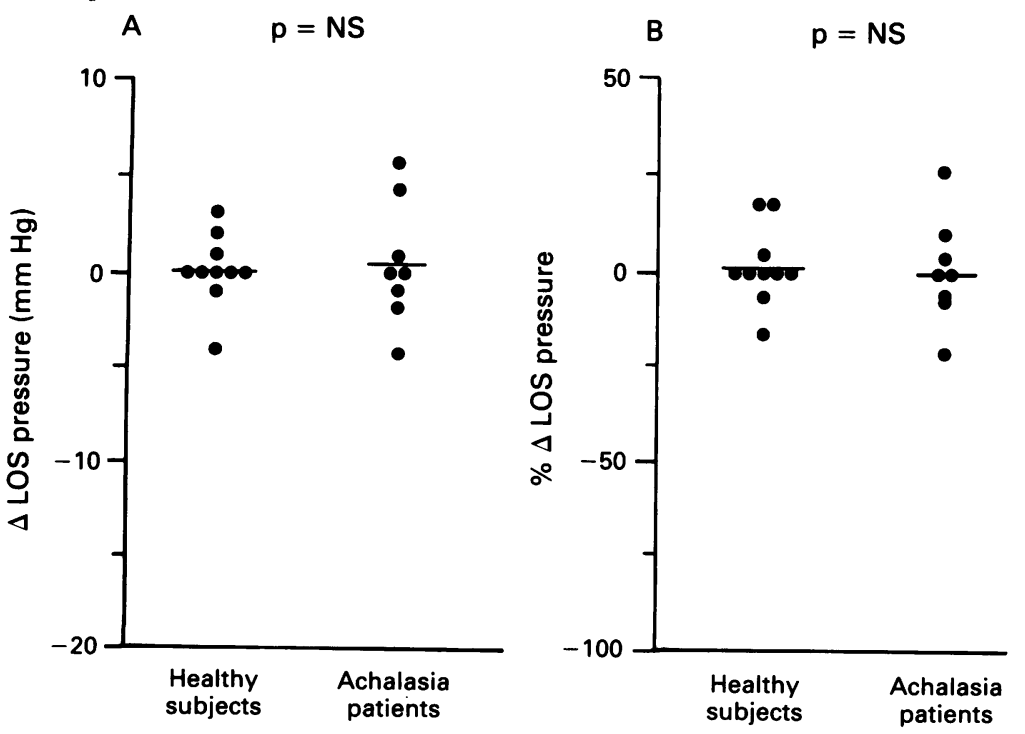

Unlike morphine, naloxone had no effect on resting lower oesophageal sphincter pressure in the healthy subjects and achalasia patients (Fig 6). Evaluation of the time course of lower oesophageal sphincter pressure changes after naloxone confirmed this observation, showing that in both groups lower oesophageal sphincter pressure did not differ significantly from the basal value at any of the time points. Swallow induced lower oesophageal sphincter relaxations were also unaffected by naloxone in both groups (Table).

\section{Discussion}

The major finding of the present study was that the lower oesophageal sphincter of achalasia patients responded to intravenous injection of morphine with a significantly greater decrease in tone than that in healthy subjects. Two lines of evidence suggest that the effect of morphine on lower oesophageal sphincter tone was mainly mediated through a $\mu$ opioid receptor. Firstly, morphine has a high affinity for the $\mu$ type among the various opioid receptors, ${ }^{18}$ and secondly the effect of morphine was almost completely reversed by a small dose of naloxone. Although naloxone at high doses may have pharmacological actions other than opioid antagonism, ${ }^{19}$ at low doses it binds mostly with $\mu$ receptors. ${ }^{1018-19}$ The second argument, however, would have
TABLE Percentage lower oesophageal sphincter relaxation after water swallows in six healthy subjects and eight achalasia patients

\begin{tabular}{lll}
\hline & Healthy subjects & Achalasia patients \\
\hline Basal & $94(3)[1 \cdot 0(0 \cdot 5)]$ & $20(7)[18(2)]$ \\
Morphine & $61(6)^{\star}\left[5 \cdot 4(0 \cdot 7)^{\star}\right]$ & $11(5)\left[10(2)^{\star}\right]$ \\
Basal & $92(2)[1 \cdot 3(0 \cdot 3)]$ & $17(5)[20(1)]$ \\
Naloxone & $95(2)[0 \cdot 9(0 \cdot 4)]$ & $14(6)[20(1)]$ \\
\hline
\end{tabular}

$\star \mathrm{p}<0.05 v$ basal

Numbers in square brackets represent residual lower oesophageal sphincter pressure in $\mathrm{mm} \mathrm{Hg}$. Data are expressed as mean (SEM).

(a)

been stronger if the blocking effect of naloxone had been shown by injecting the drug before morphine.

The location of the receptors responsible for the effect of morphine on lower oesophageal sphincter tone cannot be ascertained by our experiments. On the one hand it is known from animal studies ${ }^{20-22}$ that the effects of morphine on gastrointestinal motility may occur through stimulation of central and peripheral receptors and that the central component appears to be mediated by the vagus nerve. ${ }^{20}$ Furthermore, at the periphery, receptors sensitive to morphine have been shown at prejunctional sites along cholinergic pathways ${ }^{23}$ or directly on the smooth muscle. ${ }^{10}$ On the other hand, current evidence suggests that in man basal lower oesophageal sphincter pressure represents the sum of excitatory neural activity, inhibitory neural activity, and myogenic activity. ${ }^{24} 25$ Thus morphine may have acted either along the neural pathways or on the lower oesophageal sphincter muscle itself.

What is the possible physiological interpretation of the greater response of the lower oesophageal sphincter in achalasia and what do we gain in terms of understanding of the pathogenesis of achalasia? This is a problematical point and a few hypotheses may be considered. For example, a decrease or functional impairment of opioid nerve fibres could determine denervation supersensitivity to morphine. Although an immunocytochemical study ${ }^{8}$ showing no opioid containing nerves in the lower oesophageal sphincter in achalasia may support this contention two other observations do not. Firstly, naloxone had no effect on lower oesophageal sphincter motor function in either normals or achalasia patients, suggesting that this function is not controlled by opioid nerves. It may be argued, however, that, at the high dose we used when naloxone was tested in basal conditions, effects other than opioid receptor antagonism may have been predominant. ${ }^{19}$ Furthermore, endogenous opioids may have a physiological role in the control of lower oesophageal sphincter tone only in the fed state when a decrease in lower oesophageal sphincter pressure is known to occur. ${ }^{26}$ Secondly, the magnitude of the difference between normal subjects and achalasia patients was probably too small for a true denervation effect. Comparison between animal reports on denervation ${ }^{27-29}$ and our paper is difficult. Those studies mainly concerned the contractile response of the smooth muscle to adrenergic and cholinergic denervation and the response of the denervated muscle was somewhat variable, showing that the same degree of contraction was produced by doses of the relevant 
agonist, noradrenaline or acetylcholine, from a few times to a few 10 times smaller than for the normally innervated muscle. It may nevertheless be cautiously extrapolated that the effect of denervation on smooth muscle was generally greater than the effect of achalasia. Another explanation for morphine hypersensitivity in achalasia is impairment of non-opioid nerves located between the opioid receptor and the lower oesophageal sphincter muscle, which may have altered the lower oesophageal sphincter response. A final hypothesis is the activation of abnormal compensatory neural mechanisms for control of lower oesophageal sphincter tone in achalasia patients, induced by a direct action of morphine on the lower oesophageal sphincter muscle.

We think that further studies on peripheral opioid agonists in achalasia patients may be of interest for two reasons. Firstly, they may help to ascertain whether the receptors involved in morphine hypersensitivity are located within or outside the central nervous system. Secondly, as pharmacological treatment of achalasia is relatively inefficacious and often not well tolerated, they may indicate whether it is worth testing a small oral dose of a peripheral opioid agonist in combination with a calcium channel blocker or a nitrate in order either to achieve a greater reduction in lower oesophageal sphincter tone by combining two different relaxing mechanisms, or to reduce the dose of the traditional drugs. Whereas our data on morphine confirm that it decreases basal lower oesophageal sphincter pressure in normal subjects, 114 those on naloxone are in apparent partial disagreement with one study, ${ }^{14}$ in which a similar dose determined a modest increase of lower oesophageal sphincter pressure. This increase, however, was only intermittently significant during the 60 minute observation period. Furthermore, the different criterion of measuring lower oesophageal sphincter pressure with regard to oscillations related to the interdigestive migrating motor complex may have contributed to the different results.

Contrary to our findings on lower oesophageal sphincter tone, during swallow induced relaxations the achalasia patients showed a much smaller response to morphine than the healthy subjects. A likely hypothesis is that the drug acted on receptors located at sites different from those involved in the effect on tone, most probably along the vagal efferent neural pathways responsible for swallow induced relaxations. ${ }^{30} 31$ These pathways are thought to be severely damaged by the disease and thus unable to induce a normal relaxation of the lower oesophageal sphincter or to respond to morphine. Our results in healthy subjects, confirming inhibition of swallow induced relaxation by morphine ${ }^{13}$ in spite of a relaxing effect on lower oesophageal sphincter basal pressure, support this notion of two different sites of action.

1 Cohen S. Motor disorders of the esophagus. N Engl f Med 1979; 301: 184-92.
2 Cassella RR, Brown AL, Sayre GP, Ellis FH. Achalasia of the esophagus: pathologic and etiologic considerations. Ann Surg 1964: 160: 474-87.

3 Misiewicz JJ, Waller SL, Anthony PP, Gummer JWP. Achalasia of the cardia: pharmacology and histopathology of Achalasia of the cardia: pharmacology and histopathology of
isolated cardiac sphincteric muscle from patients with and without achalasia. $Q \mathcal{F} \mathrm{Med}$ 1969; 149: 17-30.

4 Dodds WJ, Dent J, Hogan WJ, Patel GK, Toouli J, Arndorfer RC. Paradoxical lower esophageal sphincter contraction induced by cholecystokinin-octapeptide in patients with induced by cholecystokinin-octapeptide in patients with
achalasia. Gastroenterology 1981;80:327-33.

Cohen S, Fisher R, Tuch A. The site of denervation in achalasia. Gut 1972; 13: 556-8.

6 Holloway RH, Dodds WJ, Helm JF, Hogan WJ, Dent J, Arndorfer RC. Integrity of cholinergic innervation to the lower esophageal sphincter in achalasia. Gastroenterology 1986; 90: 924-9.

7 Tottrup A, Forman A, Funch-Jensen P, Raundahl U, Andersson KE. Effect of postganglionic nerve stimulation in oesophageal achalasia: an in vitro study. Gut 1990; 31: $17-20$.

8 Aggestrup S, Uddman R, Jensen SL, Sundler F, de Muckadell OS, Holst JJ, et al. Regulatory peptides in the lower esophageal sphincter of man. Regul Pept 1985: 10: esophageal $167-78$.

9 Wattchow DA, Furness JB, Costa M, O'Brien PE, Peacock M Distributions of neuropeptides in the human esophagus. Gastroenterology 1987; 93: 1363-71.

10 Rattan S, Goyal RK. Identification and localisation of opioid receptors in the opossum lower esophageal sphincter. $\mathcal{F}$ Pharmacol Exp Ther 1983; 224: 391-7.

11 Hall AW, Moossa AR, Clark J, Cooley GR, Skinner DB. The effects of premedication drugs on the lower oesophageal high pressure zone and reflux status of Rhesus monkeys and man. Gut 1975; 16: 347-52.

12 Howard JM, Belsheim MR, Sullivan SN. Enkephalin inhibits relaxation of the lower oesophageal sphincter. $B M F$ 1982; 285: $1605-6$.

13 Dowlatshahi K, Evander A, Walther B, Skinner DB. Influence of morphine on the distal oesophagus and the lower oesophageal sphincter-a manometric study. Gut 1985; 26: 802-6.

14 Mittal RK, Frank EB, Lange RC, McCallum RW. Effects of morphine and naloxone on esophageal motility and gastric emptying in man. Dig Dis Sci 1986; 31: 936-42.

15 Jian R, Janssens J, Vantrappen G, Ceccatelli P. Influence of metenkephalin analogue on motor activity of the gastrointestinal tract. Gastroenterology 1987; 93: 114-20.

6 Fink M, Zaks A, Sharoff R, Mora A, Bruner A, Levit S, et al. Naloxone in heroin dependence. Clin Pharmacol Ther 1968; 9: $568-77$.

17 Dent J, Dodds WJ, Sekiguchi T, Hogan WJ, Arndorfer RC. Interdigestive phasic contractions of the human lowe esophageal sphincter. Gastroenterology 1983; 84: 453-60. 18 Paterson SJ, Robson LE, Kosterlitz HW. Classification of

19 Sawynok J, Pinsky C, La Bella FS. Minireview on the specificity of naloxone as an opiate antagonist. Life Sci 1979; 25: $1621-32$

20 Stewart JJ, Weisbrodt NW, Burks TF. Central and peripheral actions of morphine on intestinal transit. $\mathcal{F}$ Pharmacol Exp Ther 1978; 205: 547-55.

21 Telford GL, Hoshmonai M, Moses AJ, Szurszewski JH Morphine initiates migrating myoelectric complexes by acting on peripheral opioid receptors. Am F Physiol 1985; 249: G557-62.

22 Thomforde GM, Malagelada JR, Camilleri M, Yaksh TL. Demonstration of intrathecal and systemic morphine and ST-91 effects on fed canine upper gut motility. Dig Dis Sci 1990; 35: 1249-56.

23 Johansson IGM, Grundstrom N, Andersson RGG. Both the cholinergic and non-cholinergic components of airway excitation are inhibited by morphine in the guinea-pig. Acta Physiol Scand 1989; 135: 411-5.

24 Dodds WJ, Dent J, Hogan WJ, Arndorfer RC. Effect of atropine on esophageal motor function in humans. Am F Physiol 1981; 240: G290-6.

25 Zfass AM, Prince R, Allen FN, Farrar JT. Inhibitory beta adrenergic receptors in the human distal esophagus Am f Dig Dis 1970; 15: 303-10.

26 Dent J, Dodds WJ, Friedman RH, Sekiguchi T, Hogan WJ, Arndorfer RC, et al. Mechanism of gastroesophageal reflux in recumbent asymptomatic human subjects. $\mathcal{F}$ Clin Invest 1980; 65: 256-67.

27 Dempsey PJ, Cooper T. Supersensitivity of the chronically denervated feline heart. Am F Physiol 1968; 215: 1245-9.

28 Tsai TH, Denham S, McGrath WR. Sensitivity of the isolated nictitating membrane of the cat to norepinephrine and acetylcholine after various procedures and agents. F Pharmacol Exp Ther 1968; 164: 146-57.

29 Geffen LB, Hughes CC. Degeneration of sympathetic nerves in vitro and development of smooth muscle supersensitivity to noradrenaline. F Physiol 1972; 221: 71-84.

30 Ryan JP, Snape WJ, Cohen S. Influence of vagal cooling on oesophageal function. Am $\mathcal{f}$ Physiol 1977; 232: E159-64.

31 Reynolds RPE, El-Sharkawy TY, Diamant NE. Lower esophageal sphincter function in the cat: role of central innervation assessed by transient vagal blockade. Am $\mathcal{F}$ Physiol 1984;
246: G666-74. 